\begin{tabular}{|l|c|c|c|r|}
\hline $\begin{array}{l}\text { Cuadernos de Investigación Geográfica } \\
\text { Geographical Research Letters }\end{array}$ & 2018 & N $^{\circ} 44(2)$ & pp.581-600 & $\begin{array}{r}\text { ISSN 0211-6820 } \\
\text { eISSN 1697-9540 }\end{array}$ \\
\hline
\end{tabular}

\title{
LONG-TERM HYDROLOGICAL MONITORING IN ARID- SEMIARID ALMERÍA, SE SPAIN. WHAT HAVE WE LEARNED?
}

\author{
E. RODRÍGUEZ-CABALLERO ${ }^{1}$, R. LÁZARO ${ }^{2}$, Y. CANTÓN ${ }^{1}$, \\ J. PUIGDEFÁBREGAS ${ }^{2} \dagger$, A. SOLÉ-BENET ${ }^{2 *}$
}

\author{
${ }^{1}$ Departamento de Agronomía, Universidad de Almería, Almería, Spain. \\ ${ }^{2}$ Estación Experimental de Zonas Áridas, Consejo Superior de Investigaciones Científicas, Almería, Spain.
}

\begin{abstract}
A combination of high temporal variability and spatial heterogeneity of rainfall, soil surfaces, and plant cover is the cause of the complex hydrological response in arid/semiarid regions. Under these premises, long-term monitoring is necessary to capture drivers controlling the response of these areas and to be able to model and predict their reaction. A succinct, up-to-date review of the databases and results produced by two representative micro-catchments in the most arid extreme of Europe, Almería (SE Spain), is presented with the aim to show how the different precipitation patterns, during a 20-year period, influence the hydrological behavior on different lithologies and soil surfaces. The problems encountered about the functioning of these experimental stations, including the generation and maintenance of long-term databases, is also reviewed.
\end{abstract}

Seguimiento hidrológico a largo plazo en el árido-semiárido almeriense, $\mathrm{SE}$ peninsular. Lecciones aprendidas

RESUMEN. Una combinación de elevadas variabilidades, espacial y temporal, en precipitación, superficies del suelo y vegetación es la causa de la compleja respuesta hidrológica en las regiones áridas-semiáridas. Bajo esta premisa es necesario un seguimiento a largo plazo para conocer los factores que controlan las respuestas hidrológicas de estas regiones, poder modelizarlas y predecirlas. Se presenta una breve revisión actualizada de las bases de datos y de los resultados obtenidos en dos microcuencas representativas del semiárido almeriense, en el SE peninsular, con la finalidad de mostrar cómo diferentes patrones de precipitación influyen en el comportamiento hidrológico en diferentes litologías y superficies del suelo, en un período de unos 20 años. Además, se repasan los problemas encontrados respecto al funcionamiento y mantenimiento de estas microcuencas y en las bases de datos generadas.

Key words: data series, micro-catchment hydrology, rainfall simulation, runoff, sediment yield.

\footnotetext{
$\dagger$ This autor passed away during the last stage of this paper. The rest of the authors would like this paper to be
} a little tribute to his memory. 
Palabras clave: series de datos, hidrología de microcuencas, simulación de lluvia, escorrentía, producción de sedimentos.

Received: 25 October 2017

Accepted: 28 December 2017

*Corresponding author: Albert Solé-Benet, Estación Experimental de Zonas Áridas, Consejo Superior de Investigaciones Científicas, Carretera de Sacramento s/n, La Cañada de San Urbano, 04120 Almería, Spain. E-mail address: albert@eeza.csic.es

\section{Introduction}

A combination of high temporal variability and high spatial heterogeneity of rainfall, soil surface properties and plant cover characterizes arid and semi-arid lands (Slatyer, 1965; Pilgrim et al., 1988). In this context, the hydrological response of such areas is very complex and long-term data are needed for which an adequate monitoring is essential. However, one of the most critical issues facing Hydrology is related to the operation of a long-term climate monitoring system capable of delivering continuous and reliable data and information. Such a system is essential to know the effects of anthropogenic climate and land use changes on runoff generation and water erosion on a variety of landforms and to predict their response and evolution. Moreover, long-term observational datasets are necessary for the detection and modeling of extreme runoff events and their integration into early warning systems.

In 1990, very little information was available about the hydrology of arid/ semiarid lands in SE Spain (Puigdefábregas et al., 1999; Solé-Benet et al., 2003). Fortunately, since then, both Spanish and European research projects, e.g. LUCDEME and MEDALUS, respectively (LUCDEME, 1982; Brandt et al., 1996), promoted the installation of experimental hydrological stations and their monitoring in representative small catchments within Mediterranean regions. Some of them (e.g. Rambla Honda and El Cautivo experimental stations, in Almería, SE Spain) became long-term research sites financed by consecutive national research projects (e.g., PROGESED, PROBASE, RESEL). When the first data were available, many papers and books were published (Brandt and Thornes, 1996; Nicolau et al., 1996; Puigdefábregas et al., 1998, 1999; Cantón et al., 2001, 2002, 2004, among many others) trying to fill the lack of hydrological information in arid/semiarid lands. However, the data series were still too short to cope with the high climatic variability of these regions and their hydrological response. Consequently, runoff and erosion behaviour during large and low-frequent events, thresholds, and mechanisms of runoff production and possible changes, among other key issues, could not be considered definitive, at least during the first ten years the stations were operative.

After more than 20 years, the databases obtained from the research stations of Rambla Honda and El Cautivo allow providing clues to answer some of these questions, at least within the measured time span. A synthesis from previous papers (Puigdefábregas et al., 1998, 1999; Solé-Benet et al., 1997, 2002, 2003, 2009; 
Calvo et al., 2009; Cantón et al., 2001a,b, 2002, 2003, 2004a,b, 2011; Rodríguez-Caballero et al., 2012, 2014a,b) and of most of what has been learned on the hydrological and sediment production behaviours in the Rambla Honda and El Cautivo during 20 years is treated in this paper. More precisely, we focus on the four main aspects we consider crucial to understand system functioning and evolution: a) occurrence and frequency of rainfall; b) conditions, thresholds, and controlling mechanisms for runoff generation; c) extreme events and recurrence; d) problems encountered to generate long-term databases and to maintain the functioning of the long-term experimental stations, along with the solutions assayed.

\section{Main characteristics of the study areas}

Rambla Honda $\left(37.1297^{\circ} \mathrm{N}, 2.3713^{\circ} \mathrm{W}\right)$ and the El Cautivo $\left(37.0109^{\circ} \mathrm{N}\right.$, $2.4391^{\circ} \mathrm{W}$ ) field sites, both located in the Almería region (Fig. 1), SE Spain, are equipped research sites aiming at studying climate, hydrological and ecological processes and their interactions on two lithological contrasting locations under dry Mediterranean conditions (Puigdefábregas et al., 1999; Solé-Benet et al., 2003). Both sites are under very low grazing pressure after the abandonment of agriculture 50 years ago, at least in the areas where terrain conditions had allowed it (i.e. terraces, the lower part of alluvial fans and flat areas near ramblas).

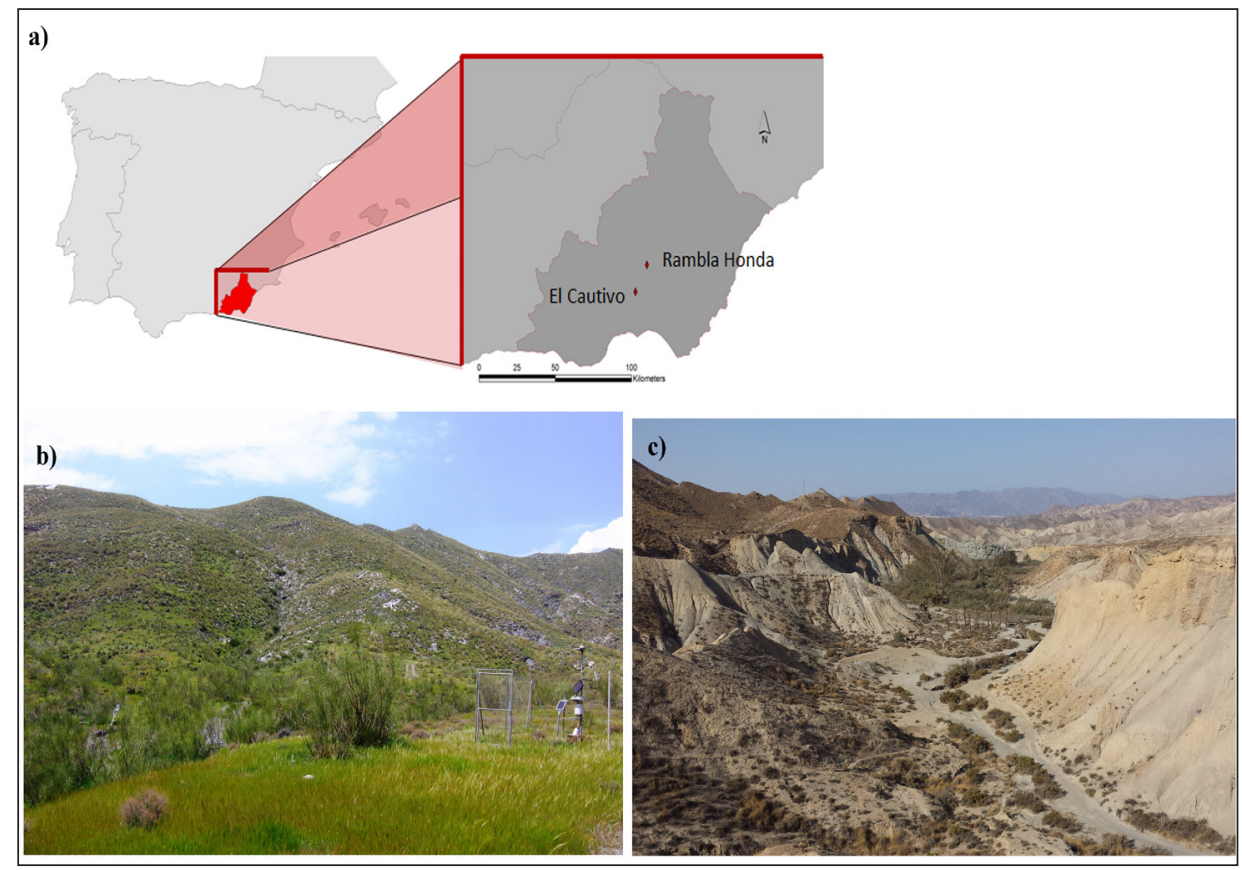

Figure 1. (a) Location of the study areas, and overview of (b) Rambla Honda catchment from its lower part, in spring after a wet winter and (c) El Cautivo catchment from its higher part. 


\subsection{Rambla Honda}

The experimental area (Fig. 1a) is located in the Southern versant of Sierra de Los Filabres, extending E-W as all Betic ranges. All the area is a semi-arid Mediterranean rangeland in a valley roughly oriented N-S with more or less preserved alluvial fans. The Rambla Honda valley, also known as Rambla del Saltador, is a tributary of Rambla de Los Nudos, at the same time tributary of Rambla de Tabernas, which discharges in the Andarax river. The lower sector of Rambla Honda is bounded by abandoned agricultural cascading terraces and by small ephemeral creeks with alluvial fans. The experimental site was precisely built in one of these creeks (Fig. 1b). On moderate to steep east-facing slopes some sets of narrow-bench terraces are also present (SoléBenet et al., 2010).

Most of the Filabres range lithology, and consequently the dominant bedrock materials for the area, is a metamorphosed Devonian-Carboniferous mica-schist with graphite and garnets crossed by many quartz veins. Frequent alluvial fans in the area are composed of gravels and sands, and the main alluvial valleys are dominated by fine sands.

The climate of the area is semiarid with long, hot summers, and an average annual precipitation and temperature of $245 \mathrm{~mm}$ and $16.5^{\circ} \mathrm{C}$ (Lázaro and Rey, 1991; Lázaro et al., 2004). Annual potential evapotranspiration (PET) is about $1600 \mathrm{~mm}$ (Lázaro et al., 2004). However, annual actual evapotranspiration (AET) in the valley, measured with a Bowen station, represents an overall water deficit somewhat larger than $100 \mathrm{~mm}$, which might be compensated by lateral hillslope runoff and eventual flash floods from the rambla (Domingo et al., 2001).

The experimental area is formed by a catena of soils and vegetation, which includes three different types of landforms: a) at the bottom, on an alluvial terrace, eutric Fluvisols with a loamy sand texture support a very open shrubland of Retama sphaerocarpa; b) at the intermediate part, on a well-preserved alluvial fan, colluvic Regosols with a gravelly loamy sand texture support an open shrubland of Anthyllis cytisoides; c) at the upper part of the catena, on steep slopes over mica-schists, skeletic Leptosols with agravelly sandy loam texture support a tussock grassland of Macrochloa tenacissima (= Stipa tenacissima L., alpha grass) (Nicolau et al., 1996; Puigdefábregas et al., 1996; López-Bermúdez et al., 2005).

Soil organic matter ranges from less than $1 \%$ in the fluvial valley to over $5 \%$ at the upper catena sector. The average electrical conductivity is very low, 0.03 to $0.2 \mathrm{dS} \mathrm{m}^{-1}$, and $\mathrm{pH}$ is neutral to moderately alkaline, from 6.5 to 8.0 (Puigdefábregas et al., 1999). Free calcium carbonate is very low, between 4.4 and $9.1 \mathrm{~g} \mathrm{~kg}^{-1}$ (Contreras and Solé, 2003).

The relatively bare patches between the more or less sparse plants from the three well-defined areas are covered by sieving crusts (Casenave and Valentin, 1992; Solé-Benet et al., 2002, 2003), from a few millimetres to over $2 \mathrm{~cm}$ thick, and better developed in the alluvial fans. These sieving crusts have an important role in hindering and/or delaying water infiltration, especially where they are well-developed (Solé-Benet et al., 2003). 


\subsection{El Cautivo}

The El Cautivo experimental site (Fig. 1c) is a badland area at the eastern part of the Tabernas Desert, over a Tortonian, upper Miocene, calcitic-gypsiferous mudstone. The area is bounded by Rambla de Tabernas at the NW, and cerro Alfaro at the SW. The complex badland landscape at Tabernas results from a combination of relief amplitude generated by tectonic uplift since the Pliocene and reactivated several times during the Pleistocene (Alexander et al., 1994). Cantón et al. (2001) describe the main properties of the Tortonian mudstone and its weathering controlled by wetting-drying cycles.

The climate is semiarid Thermomediterranean (Lázaro and Rey, 1991) with long, dry summers. The average annual temperature is $17.9^{\circ} \mathrm{C}$ and the mean annual rainfall in 30 years (1967-1997) was $239 \mathrm{~mm} \mathrm{year}^{-1}$ at Tabernas (Lázaro et al., 2001) and $209.3 \mathrm{~mm}$ at El Cautivo in the past 23 years, mostly concentrated in winter. Annual potential evapotranspiration is about $1700 \mathrm{~mm}_{\text {year }}^{-1}$ (Lázaro et al., 2004), indicating a considerable annual water deficit.

Badlands are characterized by narrow valleys mostly dissected in a NW-SE direction, clearly asymmetrical in slope gradient and plant cover (Fig. 1c). This basic asymmetry, along with the frequent changes in orientation due to incised gullies, provides a mosaic of surfaces that can be distinguished by their discontinuous perennial plant cover, exiguous annuals, rather abundant lichens, physical soil crusts, and a variety of types of erosion on different slope gradients. North- to east-facing hillslopes have $10^{\circ}$ to $40^{\circ}$ gradients and a plant cover of perennials, annuals, and lichens. Lichens (mainly Diploschistes diacapsis, Squamarina lentigera and Fulgensia fulgida) mostly cover the upper slope sectors. Annual plants, lichens and sparse shrubs coexist in the intermediate sector. In addition, a mosaic of dense annual herbs (dominated by Stipa capensis) over very sparse lichens and patches of dwarf and medium shrubs (notably Helianthemun almeriense, Hammada articulata, Artemisia barrelieri, Salsola genistoides) covers most of the footslopes. South- to west-facing slopes have gradients of $30^{\circ}$ to $77^{\circ}$ (average of $40^{\circ}$ ), and are devoid of vegetation, except limited areas with an incipient or degraded cryptogamic cover and occasional, isolated S. genistoides shrubs and, during favourable years, annual Moricandia foetida plants.

Five different soil types with dominant silty loam texture are distributed in the area (Cantón et al., 2003): 1) Epileptic Regosols with incipient soil development on steep south-facing slopes under bare surfaces; 2) Endoleptic Regosols, a somewhat more developed soil, on intermediate slopes with small contributing areas; 3) Eutric Gypsisols in divides with low slope gradients, convex curvatures and quite small contributing areas, and with gypsum accumulation; 4) Calcaric Regosols developed at the bottom of mixed colluvial material, with relatively deep $(0.9 \mathrm{~m})$ profiles, in north-facing slopes, under a dense annual and perennial plant cover; 5) well-developed Haplic Calcisols in northfacing slopes, low slope gradients, under a dense cover of annual and perennial plants. Either mineral or biological crusts, or both, cover the surfaces of the first three soil types, with contrasted erosion and hydrological behaviour (Solé-Benet et al., 1997, Cantón et al., 2001b, 2003; Chamizo et al., 2012; Rodríguez-Caballero et al., 2012). 


\section{Materials and Methods}

The Rambla Honda and El Cautivo sites are both equipped with automatic rainfall gauges ( $0.2 \mathrm{~mm}$ resolution) and capacitive gauges to measure continuous runoff. All the field data are centralised and transmitted in real time to the Estación Experimental de Zonas Áridas (EEZA) headquarters in Almería using a low-speed digital radio network facility (Puigdefábregas et al., 1999). After 2001, to avoid eventual failures in the radiotransmission system, duplicated sensors (precipitation and runoff) and low cost data loggers (Hobo system) were also installed. Precipitation data from the Tabernas weather station, belonging to the Spanish Meteorology State Agency, located between El Cautivo and Rambla Honda sites, have also been used to interpolate missing data and to analyse longer data-series.

\subsection{Rambla Honda}

The Rambla Honda experimental area has been in operation since 1990, and includes information on runoff and sediment yield on plots from $0.25 \mathrm{~m}^{2}$ (specific rainfall simulations campaigns) to $20 \mathrm{~m}^{2}$ (from September 1990 to January 2006), and from 3 nested micro-catchments: RHF1 (4.6 ha, the main one, located at the middle part of the alluvial terrace), RHF2 (3.9 ha, at the base of the mica-schist hillslope) and RHF3 (1.1 ha at the upper part of the hillslope). Data availability is from 1991 to 2013, except for the main catchment, which gauging station was damaged by an extreme event in 2008. In this review, only RHF1 and RHF2 are considered. The gauging stations located at the outlet of each catchment are H-type flumes, equipped with capacitive sensors to continuously record the depth of water flow. Half a litter tipping buckets with electronic recorders were installed at all $\mathrm{H}$-flume outlets to detect or improve precision during low flows. The gauging stations are also equipped with suspended sediment sampling systems and sediment collectors (Puigdefábregas et al., 1999). Moreover, several rainfall simulation experiments were conducted to understand the individual hydrogeomorphological response of the main surface components and landforms (Nicolau et al., 1996).

\subsection{El Cautivo}

The El Cautivo experimental area has been in operation since 1991. It is a small catchment, CAUF1 (1.8 ha), with an upper nested catchment, CAUF4 (0.5 ha) and two small creeks of order one, CAUF2 and CAUF3, smaller than $100 \mathrm{~m}^{2}$, all of them instrumented with the same type of gauging stations than Rambla Honda (i.e. H flumes, tipping-buckets at their outlet, suspended sediment sampling systems and sediment collectors). Besides the general monitoring of the catchments, several rainfall simulations have been performed to acquire information on runoff and erosion processes and rates under specific surface components and landforms and rainfall conditions (Solé-Benet et al., 1997; Cantón et al., 2002, 2014; Chamizo et al., 2012a, 2015, 2016; Rodríguez-Caballero et al., 2017).

Data for this study were taken from the H-type flumes and from rainfall simulations experiments at the main landforms (Nicolau et al., 1996; Sole-Benet et al., 1997; Chamizo et al., 2012). 


\subsection{Data analysis}

Rainfall datasets from both study areas were used to identify individual rainfall events, using a minimum inter-event time (MIT) of: a) six hours and single days for the Rambla Honda data, as the failures and consequent gaps in this station hindered a continuous data availability: b) six hours in El Cautivo, as this MIT has been used in most hydrological studies in the Mediterranean region (Usón and Ramos, 2001; Mayor et al., 2011; Chamizo et al., 2012c). For every single event the following parameters were considered: rainfall duration $(\mathrm{min})$, total rainfall $(\mathrm{mm})$, antecedent precipitation index $(\mathrm{mm})$, maximum rainfall intensity in $5 \mathrm{~min}, \mathrm{I}_{5}\left(\mathrm{~mm} \mathrm{~h}^{-1}\right)$ and, when they occur, maximum streamflow discharge $\left(\mathrm{l} \mathrm{s}^{-1}\right)$, total runoff $(\mathrm{mm})$, runoff coefficient and total sediment yield (t ha-1).

Using all rainfall events that produced runoff, for each study area we looked for changes in linearity (breakpoint) in the total rainfall - total runoff relationship using piecewise regression analysis (Toms and Lesperance, 2003). Moreover, in both areas, we selected the four largest events in terms of runoff and sediment production to show the main processes underlying runoff generation in large events and controlling climatic factors.

\section{Results and discussion}

\subsection{Frequency of rainfall and runoff events}

Average annual rainfall in Rambla Honda (1994-2013) and El Cautivo (1992-2014) was very low, 239 and $209 \mathrm{~mm}$, respectively. Annual rainfall values varied considerably among years: from 86 to $472 \mathrm{~mm}$ in Rambla Honda and from 107 to $346 \mathrm{~mm}$ in El Cautivo (Table 1). The average annual precipitation values given for both sites in previous papers (Puigdefábregas et al., 1999, Solé-Benet et al., 2003, Lázaro et al., 2004), 245 and $236 \mathrm{~mm}$, have now decreased because of low annual values in the last decade (Table 1). Besides high inter-annual variability ( $\mathrm{CV}=44$ and 36 respectively, Table 1), intra-annual monthly variability for a period of 30 years was also very high, almost always over $100 \%$, with a maximum of $207 \%$ (Lázaro et al., 2004). All the months recorded $0 \mathrm{~mm}$ at least once in a 30-year period (Lázaro et al., 2004). A typical fact characterizing the rainfall patterns of the summer season is the lack of significant rainfall amounts for two or more consecutive months. In drier than average years, the wettest month tends to be February, whereas in wetter than average years, the wettest month tends to be October (Lázaro et al., 2004). All this together makes practically impossible to forecast the amount of rainfall for a given month.

At fine temporal scale, the experimental areas registered a relatively high number of days with rain per year, with annual averages ranging from 68 days in Rambla Honda to 61 days in El Cautivo, mostly due to many days with very small rainfall (Table 1). For example, at Rambla Honda (period 1994-2013), $71 \%$ of rain events were under $3 \mathrm{~mm}$, and the average rainfall per day was $3.5 \mathrm{~mm}$, the same as El Cautivo (period 1992-2014) where $75 \%$ of rain events were under $3 \mathrm{~mm}$. 
Table 1. Annual precipitation and number of days with rain. $m=$ missing data

\begin{tabular}{|c|c|c|c|c|c|c|c|c|}
\hline \multirow{2}{*}{ year } & \multicolumn{4}{|c|}{ Rambla Honda } & \multicolumn{4}{|c|}{ El Cautivo } \\
\hline & $\mathbf{P}(\mathbf{m m})$ & all $\mathbf{P}$ & $P>3 \mathrm{~mm}$ & $P>20 \mathrm{~mm}$ & $\mathbf{P}(\mathbf{m m})$ & all $\mathbf{P}$ & $\mathrm{P}>\mathbf{3 m m}$ & $P>20 \mathrm{~mm}$ \\
\hline $91 / 92$ & $\mathrm{~m}$ & $\mathrm{~m}$ & $\mathrm{~m}$ & $\mathrm{~m}$ & 320.5 & $\mathrm{~m}$ & 8 & 5 \\
\hline $92 / 93$ & $\mathrm{~m}$ & $\mathrm{~m}$ & $\mathrm{~m}$ & $\mathrm{~m}$ & 287.4 & $\mathrm{~m}$ & 12 & 3 \\
\hline $93 / 94$ & 136.6 & 44 & 12 & 1 & 193.4 & 43 & 14 & 1 \\
\hline $94 / 95$ & 206.8 & 42 & 12 & 3 & 150.8 & 37 & 10 & 3 \\
\hline $95 / 96$ & 250.9 & 61 & 25 & 2 & 178.9 & 56 & 18 & 1 \\
\hline $96 / 97$ & 472.6 & 68 & 33 & 5 & 343.5 & 67 & 22 & 4 \\
\hline $97 / 98$ & 208.4 & 72 & 23 & 1 & 181.7 & 53 & 14 & 1 \\
\hline $98 / 99$ & 128.0 & 38 & 11 & 1 & 172.9 & 45 & 9 & 4 \\
\hline $99 / 00$ & 291.7 & 59 & 26 & 4 & 206.5 & 71 & 23 & 1 \\
\hline $00 / 01$ & 239.8 & 48 & 18 & 2 & 183.1 & 43 & 17 & 1 \\
\hline $01 / 02$ & 228.7 & 73 & 18 & 3 & 305.8 & 76 & 19 & 4 \\
\hline $02 / 03$ & 86.4 & 37 & 7 & 1 & 135.9 & 44 & 8 & 1 \\
\hline $03 / 04$ & 472.2 & 85 & 30 & 7 & 346.1 & 75 & 20 & 5 \\
\hline $04 / 05$ & 139.5 & 68 & 10 & 0 & 170.2 & 59 & 12 & 1 \\
\hline $05 / 06$ & 218.2 & 73 & 15 & 4 & 291.9 & 73 & 15 & 5 \\
\hline $06 / 07$ & 238.0 & 80 & 17 & 1 & 107.4 & 74 & 9 & 0 \\
\hline $07 / 08$ & 220.7 & 89 & 23 & 2 & 198.8 & 80 & 17 & 3 \\
\hline $08 / 09$ & 299.6 & 86 & 21 & 2 & 188.0 & 90 & 14 & 1 \\
\hline $09 / 10$ & 354.7 & 96 & 34 & 4 & 295.8 & 87 & 27 & 2 \\
\hline $10 / 11$ & 255.1 & 95 & 29 & 1 & 171.1 & 76 & 17 & 0 \\
\hline $11 / 12$ & 96.5 & 56 & 8 & 1 & 108.0 & 63 & 8 & 1 \\
\hline $12 / 13$ & 236.1 & 91 & 23 & 1 & 145.8 & 63 & 16 & 0 \\
\hline $13 / 14$ & $\mathrm{~m}$ & $\mathrm{~m}$ & $\mathrm{~m}$ & $\mathrm{~m}$ & 129.7 & 41 & 13 & 1 \\
\hline $\max$ & 472.6 & 96 & 34 & 7 & 346.1 & 90 & 27 & 5 \\
\hline $\min$ & 86.4 & 37 & 7 & 0 & 107.4 & 20 & 8 & 0 \\
\hline average & 239.0 & 68.1 & 19.8 & 2.3 & 209.3 & 61.5 & 14.9 & 2.1 \\
\hline $\mathrm{CV}$ & 43.8 & 28.4 & 41.8 & 76.1 & 36.2 & 27.1 & 34.8 & 81.6 \\
\hline
\end{tabular}

Despite torrential rains occur in these areas, they are less frequent than in more humid Mediterranean ones. In the driest hydrological year 2012, with $96.5 \mathrm{~mm}$ in Rambla Honda and $107 \mathrm{~mm}$ in El Cautivo, there were still 56 and 63 days with rain, respectively. The wettest year, 1997, recorded $472.6 \mathrm{~mm}$ in Rambla Honda and $343.5 \mathrm{~mm}$ in El Cautivo, with 68 and 67 days with rain, respectively. Average rainfall events larger than $50 \mathrm{~mm}$ in one day only occurred five times in Rambla Honda, and four times in El Cautivo in the last 20 years.

Average $\mathrm{I}_{5}$ of large events $(>20 \mathrm{~mm})$ was only $7.6 \mathrm{~mm} \mathrm{~h}^{-1}$ and the maximum $\mathrm{I}_{5}$ was $123.3 \mathrm{~mm} \mathrm{~h}^{-1}$. The largest maximum $\mathrm{I}_{5}$ was $65.5 \mathrm{~mm} \mathrm{~h}^{-1}$ for the rainfall class $10-20 \mathrm{~mm}$ (the average $\mathrm{I}_{5}$ being $18.54 \mathrm{~mm} \mathrm{~h}^{-1}$ ). The rainfall class $<1 \mathrm{~mm}$, which includes 612 events from a total of 1044, recorded a maximum $\mathrm{I}_{5}$ of $7.0 \mathrm{~mm} \mathrm{~h}^{-1}$.

Despite the relatively high number of rainfall events, the number of runoff events in both sites was very low because of the low magnitude of most rainfall events. The number of significant erosive events was also low. Figure 2 shows the proportion of 
runoff and non-runoff events produced by rainfall in $5 \mathrm{~mm}$ intervals. Below $5 \mathrm{~mm}$, RHF2 (Rambla Honda) shows the lowest proportion of runoff events. The highest proportion of runoff events is found in the rainfall interval $20-25 \mathrm{~mm}$. The lowest proportion of nonrunoff events is produced in the rainfall interval $15-20 \mathrm{~mm}$ and above $20 \mathrm{~mm}$, all rainfalls produced runoff. Below $5 \mathrm{~mm}$ of rainfall, CAUF1 (El Cautivo) shows a much higher proportion of runoff events than Rambla Honda. The highest proportion of runoff events is found in the rainfall intervals between $5-20 \mathrm{~mm}$, somewhat lower than in Rambla Honda. This is due to the lower runoff coefficients in El Cautivo. In this catchment, all rainfall events above $15 \mathrm{~mm}$ produced runoff.
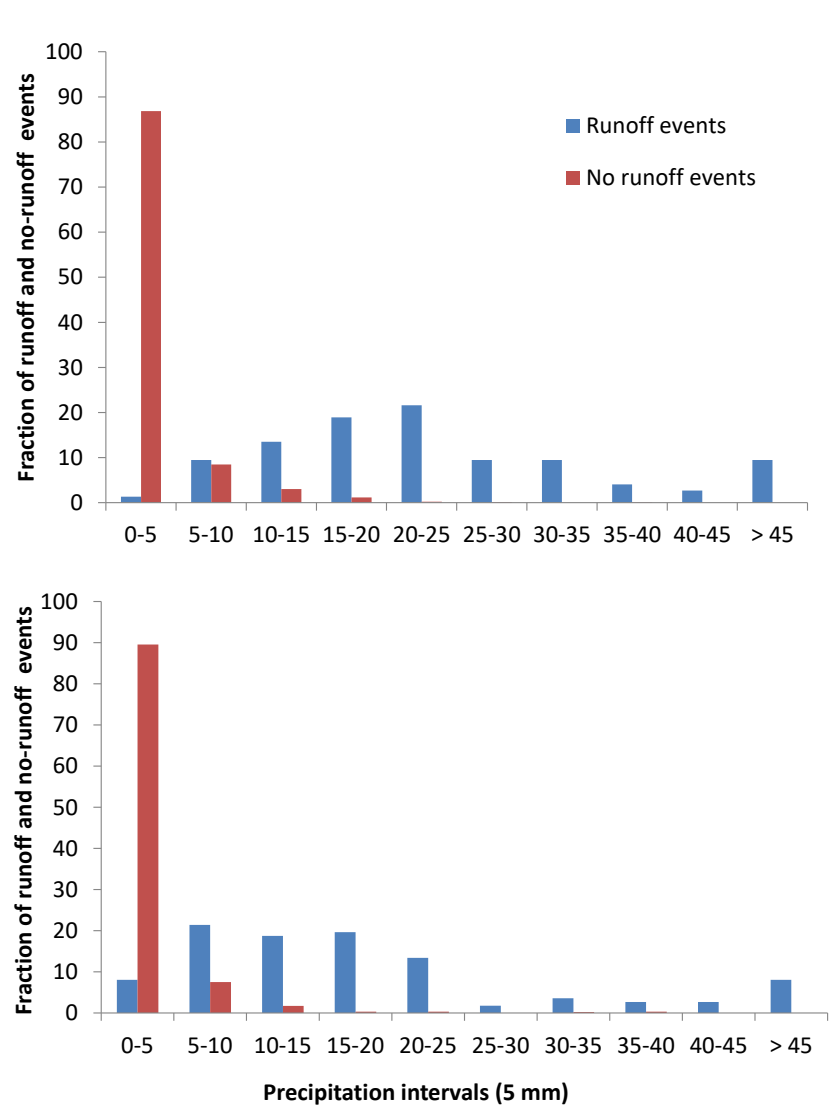

Figure 2. Fraction of runoff and non-runoff events produced by rainfall intervals of $5 \mathrm{~mm}$ at RHF2 (Rambla Honda) during the hydrological years 1994 to 2013 (upper panel) and at CAUF1 (El Cautivo) during the hydrological years 1992 to 2014 (lower panel).

The complex precipitation-runoff responses in the two areas justify that the understanding of hydrological behaviour in semiarid regions requires long-term monitoring to obtain long data-series. 
4.2. Thresholds and changes in runoff generation types and the important role of soil properties and soil-surface types

At small plot scale over different soil surfaces and landforms at both sites, rainfall simulations have revealed contrasting infiltration rates (Tables 2 and 3), with a clear dominance of infiltration excess overland flow generation mechanisms. At Rambla Honda, this is because a large part of the soil surfaces is on mica-schist outcrops, on shallow soils, and on deeper soils covered by sieving crusts. In El Cautivo, the main reason is the dominance of shallow soils more or less crusted (by mineral and biological soil crusts). A small part of the soil surfaces at both study sites, usually located at the footslope, has a high infiltration capacity, especially below plants (Tables 2 and 3).

Table 2. Steady infiltration rate $\left(F c\right.$, in $\left.\mathrm{mm} \mathrm{h}^{-1}\right)$ after 30 min of rainfall simulation $\left(50 \mathrm{~mm} \mathrm{~h}^{-1}\right)$ on the different landforms described in Rambla Honda.

\begin{tabular}{|c|c|c|c|}
\hline Landform & Dominant plant cover & Fc & reference \\
\hline Alluvial terrace & Retama sphaerocarpa & $23.0 \pm 11.4$ & Nicolau et al. (1996) \\
Alluvial Fan & Anthyllis cythisoides & $12.0 \pm 5.2$ & Nicolau et al. (1996) \\
Mica Schist & Macrochloa tenacissima & $11.7 \pm 2.9$ & Nicolau et al. (1996) \\
\hline
\end{tabular}

Table 3. Steady state infiltration rate $\left(F c\right.$, in $\left.\mathrm{mmh}^{-1}\right)$ after 60 min of rainfall simulation $\left(55 \mathrm{~mm} \mathrm{~h}^{-1}\right)$ on the main surface components at El Cautivo.

\begin{tabular}{|c|c|c|c|}
\hline Landforms & Dominant soil surface & Fc & reference \\
\hline S-slopes & Physical soil crusts & $8.8 \pm 4.9$ & Chamizo et al. (2012) \\
N-slopes & Biocrusts & $8.9 \pm 6.2$ & Chamizo et al. (2012) \\
Footslopes & Vascular plants & $15.1 \pm 12.6$ & Solé-Benet et al. (1997) \\
\hline
\end{tabular}

When rainfall exceeds the infiltration capacity of less permeable areas (e.g., very shallow soils and mica-schist outcrops in Rambla Honda hillslopes, and physical and biological soil crusts at El Cautivo), runoff initiates and contributes to the saturation of downslope areas with a higher infiltration capacity. Those areas are vegetated patches or well-drained soils at the footslopes of both Rambla Honda and El Cautivo. Once these areas are saturated or rainfall intensity exceeds their infiltration capacity, runoff can continue downslope and reach the channel network (Nicolau et al., 1996; Puigdefábregas et al., 1998, 1999 for Rambla Honda; Cantón et al., 2001, 2002; and Rodríguez-Caballero et al., 2014 for El Cautivo).

Thus, at both sites two different mechanisms can be identified: i) infiltration excess overland flow generation during short intense rainstorms, and ii) saturation of the uppermost layer of soils within areas with higher surface permeability (e.g. vegetation patches) during long duration and high magnitude events (Puigdefabregas et al., 1998, 1999). The dominance of one of those two mechanisms depends on rainfall properties, antecedent soil moisture conditions, plant cover type and soil surface characteristics of the different sectors within the catchment, and determines the overall catchment 
hydrological behavior (Puigdefábregas et al., 1999 for Rambla Honda and RodríguezCaballero et al., 2014 for El Cautivo).

\subsubsection{El Cautivo}

El Cautivo catchment has $30 \%$ of its surface oriented to the south and covered by a dense layer of physical soil crusts with very low infiltration capacity (Table 3), directly connected to the channel network. As infiltration-excess is the dominant overland flow mechanism over these areas, runoff is always observed when rainfall intensity exceeds the very low infiltration capacity of the physical soil crusts. This fact explains why rainfall events lower than $5 \mathrm{~mm}$ produced runoff in a larger number of events in El Cautivo than in Rambla Honda (Fig. 2). Thus, about $10 \%$ of rainfall events yield runoff, most of them (about $70 \%$ ) characterized by low magnitude precipitation $(<21 \mathrm{~mm})$. Lichen-dominated biocrust-areas within the upper part of north-facing hillslopes are also characterized by low infiltration capacity (Table 3). However as described by Cantón et al. (2001, 2002) and Rodríguez-Caballero et al. (2014), runoff generated on these patches is re-infiltrated within the relatively densely vegetated footslopes. This process of run-on redistribution reduces the effective drainage area of the catchment and results in relatively low runoff with high sediment concentration. This occurs because most runoff comes from the eroded bare hillslopes (Cantón et al., 2001; Rodríguez-Caballero et al., 2014).

During large events (>21 mm), usually characterized by lower intensities and high duration under wet conditions, rainwater, along with the water surplus from upslope biocrust-dominated-areas, can saturate the soil underneath vegetation, increasing catchment connectivity and the effective drainage area (Rodríguez-Caballero et al., 2014). At this point, catchment runoff is formed by a combination of infiltration-excess overland flow, generated from source areas, and runoff produced by partial saturation of the soil under plants (Rodríguez-Caballero et al., 2014), which produces a sharp threshold in the hydrological response of the system, as shown in Figure 3.

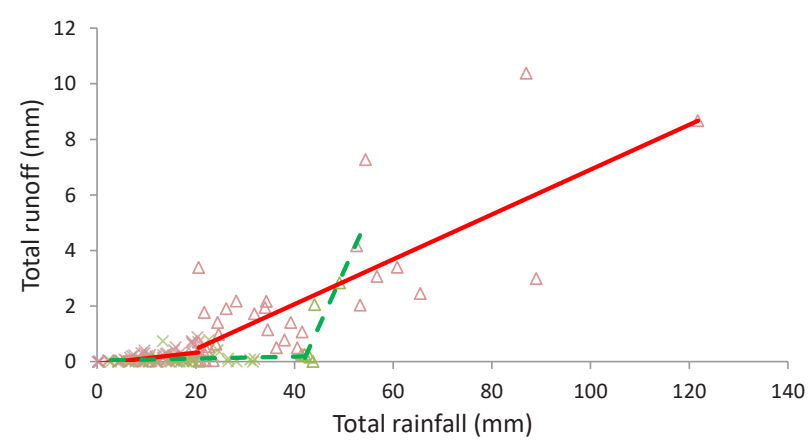

Figure 3. Relationship between total rainfall amount the and measured runoff at the main catchment outlet CAUF1 (El Cautivo, red line) and RHF2 (Rambla Honda, green line), for all runoff events. The break points result from the piecewise regression analyses. Once rainfall amounts rise above the breakpoints a strong change in the slope ratio between runoff and rainfall is observed. 
A good example of such hydrological behaviour can be found during the event occurred on the 7th November 1992 (Fig. 4, Table 4). Runoff started after less than $10 \mathrm{~mm}$ of cumulated rainfall and produced small peaks (around 21:00 and 23:00 on the 7th November) that can be observed only a few minutes after the first rainfall peaks. The first runoff peak occurred when rainfall intensity exceeded the infiltration capacity of bare marls $\left(8.8 \pm 4.9 \mathrm{~mm} \mathrm{~h}^{-1}\right)$, and runoff and sediments from these areas rapidly reached the catchment outlet. After a period of about eight hours without precipitation, a second precipitation-runoff event occurred. This time, the soil of the catchment was wet after the previous $25 \mathrm{~mm}$ of rainfall and less than $15 \mathrm{~mm}$ of additional rainfall, though with a somewhat higher intensity than the previous one, produced two very high runoff peaks (between 14:00 and 15:00 on the 8th November), indicating that the whole catchment was hydrologically connected. These peaks occurred after more than $30 \mathrm{~mm}$ of cumulated rainfall, and runoff discharge was more than twice the runoff measured during the previous peak.
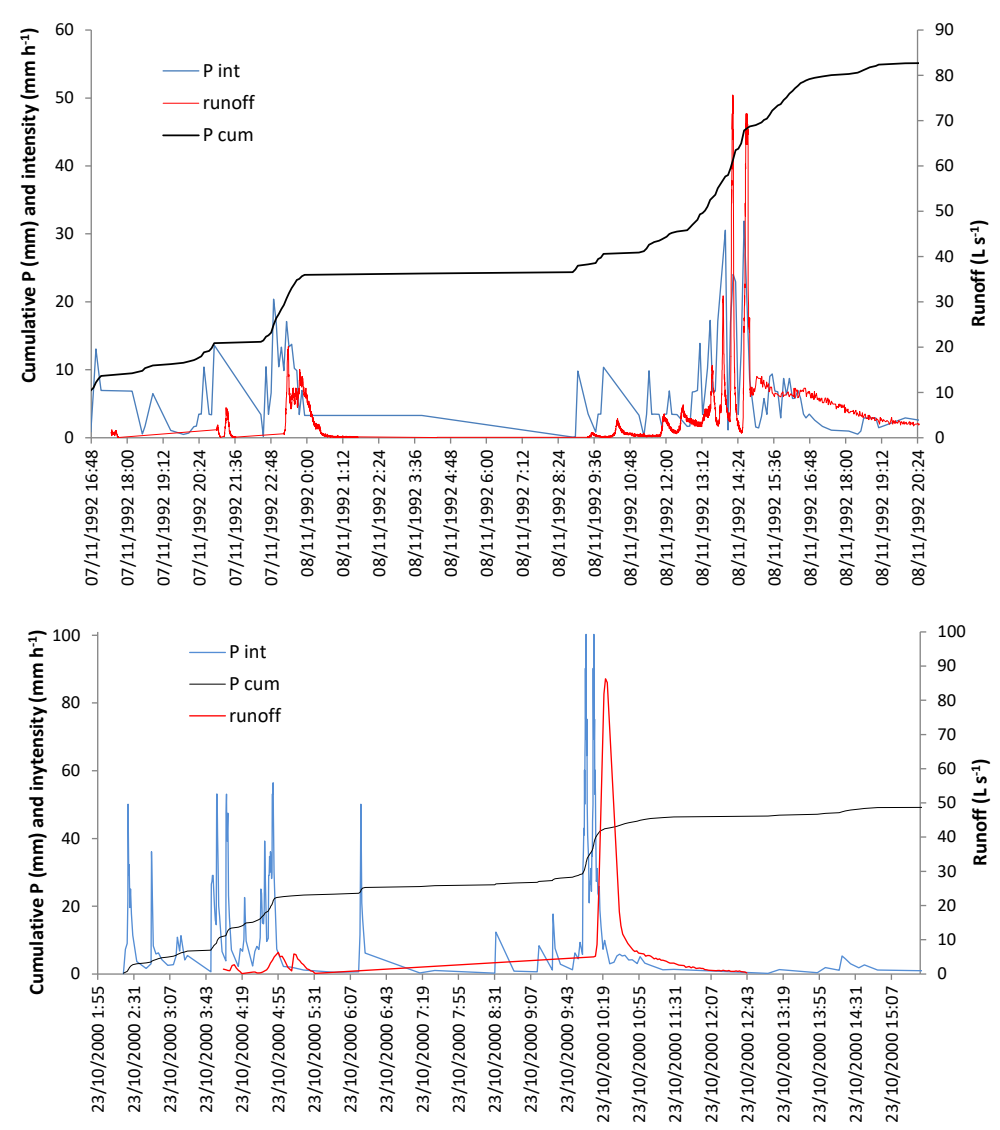

Figure 4. Runoff, cumulated rainfall $(P$ cum) and rainfall intensity $(P$ int $)$ recorded at (upper panel) CAUF 1, main H-flume in El Cautivo, during the event of 7th November 1992, and (lower panel) RHF1, main H-flume in Rambla Honda, during the event of 23th October 2000. 
Table 4. Main characteristics of major events in the main El Cautivo catchment, CAUF1, between 1990 and 2013.

\begin{tabular}{|c|c|c|c|c|c|c|c|c|c|c|}
\hline Event & $\begin{array}{c}\mathbf{P} \\
\mathrm{mm}\end{array}$ & $\begin{array}{c}\text { API } \\
\mathrm{mm}\end{array}$ & $\begin{array}{c}\mathbf{I} \text { max } \\
\mathrm{mm} \mathrm{h}^{-1}\end{array}$ & $\begin{array}{c}\mathbf{I}_{5} \mathbf{m a x} \\
\mathrm{mm} \mathrm{h}^{-1}\end{array}$ & $\begin{array}{c}\text { Q max } \\
\mathrm{L} \mathrm{s}^{-1}\end{array}$ & $\begin{array}{c}\text { Tot Rnf } \\
\mathrm{mm}\end{array}$ & $\begin{array}{c}\text { Rnf Coef } \\
\%\end{array}$ & $\begin{array}{c}\text { Rel Rnf } \\
\%\end{array}$ & $\begin{array}{c}\text { Tot Sed } \\
\mathrm{t} \mathrm{ha}^{-1}\end{array}$ & $\begin{array}{c}\text { Rel Sed } \\
\%\end{array}$ \\
\hline $07 / 11 / 1992$ & 87 & 0.0 & 32 & 32 & 50 & 10 & 12 & 23.8 & 3.8 & 15.3 \\
$28 / 09 / 1997$ & 61 & 19.7 & 65 & 65 & 79 & 3 & 6 & 7.1 & 6.2 & 24.9 \\
$23 / 10 / 2000$ & 53 & 38.7 & 105 & 67 & 55 & 2 & 4 & 4.8 & 3.9 & 15.7 \\
$09 / 11 / 2001$ & 26 & 9.1 & 26 & 20 & 8 & 2 & 7 & 4.8 & 1.0 & 4.0 \\
\hline
\end{tabular}

P: total rainfall; API: antecedent precipitation index; I max: maximum rainfall intensity; $\mathrm{I}_{5}$ max: maximum rainfall intensity in 5 min; Q max: maximum streamflow discharge; Tot Rnf: total runoff; Rnf Coef: runoff coefficient; Rel Rnf: relative runoff; Tot Sed: sediment yield; Rel Sed: relative to all runoff events.

\subsubsection{Rambla Honda}

The upper part of this catchment is characterized by very shallow sandy loam soils with low permeability, where runoff easily starts in response to short-lived intense rainfall events just over $3 \mathrm{~mm}$, showing a "typical" infiltration excess response (Puigdefábregas et al., 1999). However, the alluvial fans and terraces with more permeable soils present much higher thresholds for runoff occurrence (Table 2). Thus, runoff is rare in the lower sectors and mostly occurs in response to low-frequency high magnitude events, especially under wet conditions, when the subsurface layer of the alluvial fan is saturated. The result is the occurrence of 48 runoff events recorded in RHF2 during 20 years with a mean annual runoff of $4 \mathrm{~mm}$, though one single event yielded $48 \mathrm{~mm}$. For this reason, there is no relationship between runoff and rainfall intensity $\left(r^{2}=0.0435, p=0.244\right)$.

Once the subsurface layer of the alluvial fan at the mica-schist footslope (characterized by thick loamy sand soils with a better infiltration capacity) is saturated, the catchment becomes hydrologically connected and the amount of water that reaches the channel network increases considerably. As we can see in Figure 4 , the rainfall event that occurred on $23^{\text {th }}$ October 2000 during several hours of intense rainfall (several peaks between 50 and $60 \mathrm{~mm} \mathrm{~h}^{-1}$ ) and more than $20 \mathrm{~mm}$ of total precipitation, produced quite small runoff at RHF2 outlet, indicating that most of the runoff water from the upper sector of the catchment was infiltrated in the upper part of the alluvial fan, where the gauging station is located. However, runoff increased exponentially during the last rainfall peak (about $100 \mathrm{~mm} \mathrm{~h}^{-1}$ ), once the runoff threshold indicated in Figure 3 was reached (over $40 \mathrm{~mm}$ ). At this point, the catchment is hydrologically fully-connected. During this event, the runoff measured at the 12 runoff plots installed at different points of the catena was $8.3 \mathrm{~mm} \pm 2.9 \mathrm{~mm}$ on the alluvial fan and $13.35 \mathrm{~mm} \pm 2.3 \mathrm{~mm}$ on the mica-schist hillslope, confirming the hydrological behaviour of these two sectors of the catchment.

It is important to mention the role of sieving crusts (Casenave and Valentin, 1992; Solé-Benet et al., 2002, 2003) in Rambla Honda, especially in the bare patches of the 
alluvial fan, where a thin layer of fines acts as a temporal saturation layer causing runoff under high rainfall magnitudes. Moreover, patches with large plants like Anthyllis and Retama act as sinks under all types of rainfall.

When comparing the two events of Figure 4, one can see that Rambla Honda and El Cautivo have somewhat different hydrological responses. In RHF1 and RHF2 (Rambla Honda) there was a delay between rainfall intensity peaks and maximum runoff discharge, more common from areas dominated by saturation overland flow, while in El Cautivo the response was essentially controlled by the infiltration excess mechanism.

The hydrological thresholds change not only across space (in relation to the soil and to the soil surface features) but also over time. For example, in the year 2003, a pest affected most Anthyllis cytisoides plants in Rambla Honda, which finally died, and had an impact on the hydrological response from 2003 onwards in the areas covered with this shrub (mostly the half upper part of alluvial fans), until the recovery of new plants few years later (unpublished RESEL reports 2004 and 2005, following Rojo-Serrano and Sánchez-Fuster, 1997). This hydrological change is another reason justifying the need for long-term monitoring.

\subsection{Extreme events}

The long-term monitoring of climate, hydrology and sediment yield also provided continuous and reliable information to identify the major extreme erosive events that occurred within the monitored sites and offer the possibility to quantify their relevance in terms of total runoff and sediment production. As seen in Table 5, the four largest events occurred at Rambla Honda during the last two decades produced a total runoff and sediment yield of only $15 \mathrm{~mm}$ and $0.5 \mathrm{t} \mathrm{ha}^{-1}$, but they represented more than $80 \%$ and $90 \%$ of total runoff and sediments measured during that period. At El Cautivo site, the four major events described in Table 4 produced more runoff $(17 \mathrm{~mm})$ and sediments $\left(14.9 \mathrm{t} \mathrm{ha}^{-1}\right)$ than the largest events recorded at Rambla Honda. However, as described before, threshold for runoff initiation at El Cautivo was lower than at Rambla Honda (Fig. 3), resulting in a higher number of runoff events; for this reason, major events only represented $40 \%$ and $60 \%$ of total runoff and erosion measured since 1992 at this site.

Figure 5 shows the relationship between total rainfall, rain intensity, runoff, and sediment yield during the four selected erosive events at both Rambla Honda and El Cautivo. At El Cautivo, runoff production during these maximum events increased with precipitation amount, and only occurred once vegetated areas were saturated and the catchment was fully connected. Sediment yield, on the other hand, was controlled by the combined effect of maximum peak discharge and total runoff (Rodríguez-Caballero et al., 2014). Thus, there is not a clear relationship neither with intensity nor with precipitation amount. At Rambla Honda, extreme runoff events carrying maximum sediments seem to be controlled by rainfall intensity. This assumption is strongly influenced by the event occurred of 10th October 2008 (Fig. 6) with the largest runoff, which overflowed the 
$\mathrm{H}$-flume (with a maximum capacity of $340 \mathrm{~L} \mathrm{~s}^{-1}$ ) and an estimation had to be calculated knowing the maximum flow footprint $\left(560 \mathrm{~L} \mathrm{~s}^{-1}\right)$. This event had a total precipitation of $73 \mathrm{~mm}$ (Table 5), a maximum $\mathrm{I}_{5}$ of $120 \mathrm{~mm} \mathrm{~h}^{-1}$, and a return period of 20 years. A deeper look into this event shows that, as it was expected by the normal behaviour of the catchment (cf. 4.2.2), the flood occurred after five hours of intense and large rainfall $(73.5 \mathrm{~mm})$ and did not coincide with the peak of maximum rainfall intensity. During this five-hour period, most of the rainfall infiltrated into the soils, contributing to the saturation of the uppermost soil layers at the end of the event, when the catchment was fully hydrologically connected and the runoff peak was observed. It should be emphasized that catchment connectivity is the crucial factor for the occurrence of runoff during extreme events, and when this connectivity occurs, both Rambla Honda and El Cautivo sites have their soils partially saturated. Consequently, the combination of large rainfall events and relatively wet conditions is necessary.

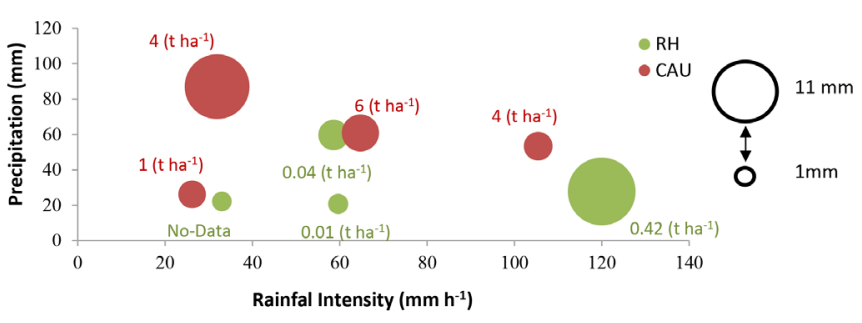

Figure 5. Runoff (circles) and sediment yield (data above-below circles) from RHF2 (Rambla Honda) and CAUF1 (El Cautivo) in relation to both rainfall magnitude and intensity for the largest events (Rodríguez-Caballero et al., 2014b).

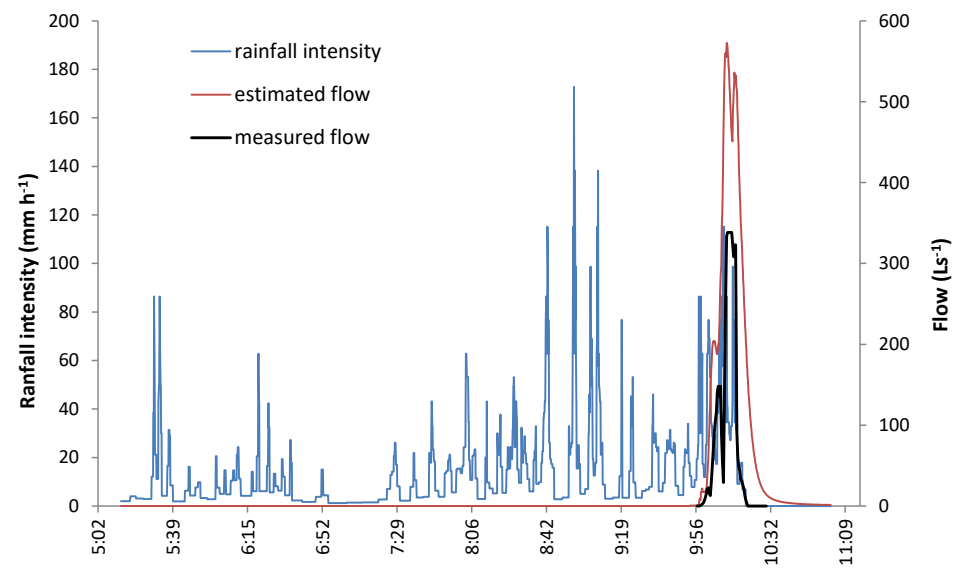

Figure 6. Rainfall intensity and stream flow recorded at RHF1 (main H-Flume, Rambla Honda) during the event of 10th October 2008. The truncated peak indicates that during 5 min the $H$-flume was overflowing. For this reason maximum flow had to be estimated from the maximum water footprint section. 
Table 5. Main characteristics of major events in RHF1, Rambla Honda, between 1994 and 2013

\begin{tabular}{|c|c|c|c|c|c|c|c|c|c|c|}
\hline Event & $\begin{array}{c}\text { P } \\
\mathrm{mm}\end{array}$ & $\begin{array}{c}\text { API } \\
\mathrm{mm}\end{array}$ & $\begin{array}{c}\text { Imax } \\
\mathrm{mm} \mathrm{h}^{-1}\end{array}$ & $\begin{array}{c}\mathbf{I}_{\mathbf{5}} \mathbf{m a x} \\
\mathrm{mm} \mathrm{h}^{-1}\end{array}$ & $\begin{array}{c}\text { Q max } \\
\mathrm{L} \mathrm{s}^{-1}\end{array}$ & $\begin{array}{c}\text { Tot Rnf } \\
\mathrm{mm}\end{array}$ & $\begin{array}{c}\text { Rnf Coef } \\
\%\end{array}$ & $\begin{array}{c}\text { Rel Rnf } \\
\%\end{array}$ & $\begin{array}{c}\text { Tot Sed } \\
\mathrm{t} \mathrm{ha}^{-1}\end{array}$ & $\begin{array}{c}\text { Rel Sed } \\
\%\end{array}$ \\
\hline $15 / 10 / 1994$ & 60 & 3.1 & 59 & 32 & 57 & 2 & 4 & 13.1 & 0.04 & 7.6 \\
$11 / 09 / 1996$ & 21 & 20.2 & 60 & 40 & 57 & 1 & 5 & 5.7 & 0.01 & 2.1 \\
$10 / 09 / 2008$ & 35 & 0.5 & 240 & 149 & 42 & 1 & 3 & 5.7 & 0.02 & 3.8 \\
$10 / 10 / 2008$ & 73 & 3.7 & 172 & 57 & 573 & 11 & 15 & 64.3 & 0.42 & 80.8 \\
\hline
\end{tabular}

P: total rainfall; API: antecedent precipitation index; I max: maximum rainfall intensity; $\mathrm{I}_{5}$ max: maximum rainfall intensity in $5 \mathrm{~min}$; Q max: maximum streamflow discharge; Tot Rnf: total runoff; Rnf Coef: runoff coefficient; Rel Rnf: relative runoff; Tot Sed: sediment yield; Rel Sed: relative to all runoff events.

\subsection{Difficulties, sustainability and importance of long-term monitoring}

Long-term monitoring programs are essential for the understanding of the variable and complex hydrological behavior of arid-semiarid regions. In dry environments, looking at fine time scales is essential to obtain information about processes, especially those from extreme events, such as rainfall, which are the main drivers of landscape change. Nevertheless, both the implementation and the maintenance of long-term hydrological stations is not an easy task, due to logistical and technical difficulties:

(i) Often, the main difficulty for long-term monitoring (e.g. permanent research facilities) is a financial one, as funding is required for both the implementation and the continuous maintenance, which also requires specialized field personnel, sometimes overlooked when master or PhD students do the tasks. Moreover, there is the paradox that funding comes mainly from specific research projects, the time scale of which is usually much shorter than that of geomorphic processes.

(ii) Since research institutions do not usually have a land property allowing the installation of monitoring stations, a frequent difficulty for long-term monitoring is to keep the landowner's permissions over time.

(iii) The physical infrastructure requires frequent visits to avoid not only sensor malfunction but also leakages and eventual breakages of gauges (pluviometers, $\mathrm{H}$-flumes, electronic sensors, etc.), all of which are at the origin of loss or poor quality data. Remotely real-time transmitted data, besides facilitating data acquisition from remote areas, is an early warning-system for sensor malfunction, allowing an earliest-as-possible solution. Duplicating measurements and in-situ data storage with low-cost sensors and loggers (HOBO type) is a good technical solution to minimize data loss.

(iv) Periodical calibration of sensors, tipping buckets and other sensitive material is necessary to avoid a progressive drift of the measured variables.

(v) The occasional occurrence of hyper-concentrated flows, like in El Cautivo, a badland environment, usually causes clogging of gauging devices and sensors because of the nature of the detached marly soil and regolith, requiring an additional manpower and time for cleaning between events. 
In arid-semiarid areas, where runoff events normally occur with a very low frequency, it may take a long time to collect a good series of data to test homogeneity. Moreover, data obtained in arid-semiarid regions should be used with caution when trying to extrapolate data to either larger or different areas as their spatial heterogeneity (soil depth, vegetation type and cover, rooting depth, soil crusts) and high variability of rainfall and other meteorological data are very large. For those reasons, extrapolations can only be applied on very similar environmental conditions.

\section{Conclusions}

Results obtained during the last two decades on two complex semiarid catchments, characterized by low effective rainfalls, offer the possibility to understand and model their complex hydrological functioning. During most rainfall events (small rains), only a small fraction of the catchments contributed to total runoff, whereas during the few largest events recorded in this 20-year period, source areas were saturated, catchments fully connected and runoff and sediment yield increased exponentially. These processes were controlled by the specific spatial arrangement of different landforms and surface components such as plants and other biological forms, like biocrusts, with contrasting hydrological response. Thus, it is of paramount importance to know the different spatial scales at which different precipitation patterns, also very variable in these regions, produce variable hydrological processes. Only long-term monitoring systems can respond to the question of how the different landforms and soil surface components interact in time and space. These longterm monitoring systems need to be complemented, however, with punctual experiments over the different surface components, which also need a thorough characterization. In both catchments, the few large events during which the catchment was fully connected represented the majority of runoff and sediment production during the 20 years of monitoring. As these events had long recurrence periods, it is obvious that long-term monitoring at the catchment scale is essential, not only to understand, model and predict runoff and sediment yield processes, but also to correctly characterize total runoff and sediment yield rates. This is particularly true in drylands, where the number of runoff events is limited by the low overall precipitation and rainfall types producing runoff.

Though 20 years of monitoring might seem enough to achieve these objectives, larger events with longer recurrence periods could be not recorded. During these very extreme events perhaps other processes and mechanisms are activated. For this reason, it is difficult to extrapolate current knowledge under the demand for longer time series. Moreover, the climate is changing and global models predict future changes that could be out of the range of current climatic records, making difficult the prediction based on current knowledge.

\section{Acknowledgements}

The following research projects have partly contributed to support the maintenance of field installations, data gathering, and personnel: MEDALUS (contract no. EV5VCT92-0128), financed by the EEC European Union; PROHIDRADE (AMB95-0986), PROGESED (HID97-0581), EPOHIDRO (HID98-1056), PROHISEM (REN2001- 
2268-C02-01), CANOA (CGL2004-04919-C02-01), PROBASE (CGL2006-11619/ HID), BACARCOS (CGL2011-29429), RESUCI (CGL2014-59946-R), DINCOS (CGL2016-78075-P), financed by the Spanish I+D program; COSTRAS (RNM 3614) financed by Junta de Andalucía; and RESEL (network of Spanish field stations measuring soil erosion), supported by the General Directorate for Nature Conservancy of the Spanish Ministry of Agriculture and Environment. Special thanks to Alfredo Duran for field work assistance, to Sebastián Vidal for his help in data acquisition, and to the Viciana family, owner of El Cautivo site.

\section{References}

Alexander, R.W., Harvey, A.M., Calvo, A., James P.A., Cerdà, A. 1994. Natural stabilization mechanisms on badland slopes: Tabernas, Almería, Spain. In: C. Millington, K. Pye (Eds.), Environmental Change in Drylands: Biogeographical and Geomorphological Perspectives. John Wiley \& sons, pp. 85-111.

Brandt, C.J., Thornes, J.B. (Eds.) 1996. Mediterranean desertification and land use. John Wiley \& sons, Chichester, $554 \mathrm{pp}$.

Calvo-Cases, A., Alexander, R., Arnau-Rosalén, E., Bevan, J., Cantón, Y., Lázaro, R., Puigdefábregas, J., Solé-Benet, A. 2009. Interacción de procesos geomórficos y distribución de componentes de la superficie del suelo en relación a la evolución de los abarrancamientos de Tabernas (Almería). Cuadernos de Investigación Geográfica 35 (1), 43-62. http://doi. org/10.18172/cig.1212.

Cantón, Y., Solé-Benet, A., Queralt, I.,Pini, R. 2001a. Weathering of a gypsum-calcareous mudstone under semi-arid environment at Tabernas, SE Spain: laboratory and field-based experimental approaches. Catena 44, 111-132. https://doi.org/10.1016/S0341-8162(00)00153-3.

Cantón, Y., Domingo, F., Solé-Benet, A., Puigdefábregas, J. 2001b. Hydrological and erosion response of a badlands system in semiarid SE Spain. Journal of Hydrology 252, 65-84. https://doi.org/10.1016/S0022-1694(01)00450-4.

Cantón, Y., Domingo, F., Solé-Benet, A., Puigdefábregas, J. 2002. Influence of soil surface types on the overall runoff of the Tabernas badlands (SE Spain). Field data and model approaches. Hydrological Processes 16, 2621-2643. http://doi.org/10.1002/hyp.1052.

Cantón, Y., Solé-Benet, A., Lázaro, R. 2003. Soil-geomorphology relations in gypsiferous materials of the Tabernas desert (Almeria, SE Spain). Geoderma 115, 193-222. http://doi.org/10.1016/ S0016-7061(03)00012-0.

Cantón, Y., Del Barrio, G., Solé-Benet, A., Lázaro, R. 2004a. Topographic controls on the spatial distribution of ground cover in a semiarid badlands area. Catena 55, 341-365. http://doi. org/10.1016/S0341-8162(03)00108-5.

Cantón, Y., Solé-Benet, A., Domingo, F. 2004b. Temporal and spatial patterns of soil moisture in semiarid badlands of SE Spain. Journal of Hydrology 285, 199-214. http://doi.org/10.1016/j. jhydrol.2003.08.018.

Cantón, Y., Solé-Benet, A., Asensio, C., Chamizo, S., Puigdefábregas, J. 2009. Aggregate stability in range sandy loam soils. Relationships with runoff and erosion. Catena 77, 192-199. http:// doi.org/10.1016/j.catena.2008.12.011.

Cantón, Y., Solé-Benet, A., De Vente, J., Boix-Fayos, C., Calvo-Cases, A., Asensio, C., Puigdefábregas, J. 2011. A review of runoff generation and soil erosion across scales in semiarid south-eastern Spain. Journal of Arid Environments 75, 1254-1261. http://doi. org/10.1016/j.jaridenv.2011.03.004. 
Cantón Y., Román J.R., Chamizo, S., Rodríguez-Caballero, E., Moro, M.J. 2014. Dynamics of organic carbon losses by water erosion after biocrust removal. Journal of Hydrology and Hydromechanics 62, 258-268. https://doi.org/10.2478/johh-2014-0033.

Chamizo, S., Cantón, Y., Lázaro, R., Solé-Benet, A., Domingo, F. 2012a. Crust composition and disturbance drive infiltration through biological soil crusts in semiarid ecosystems. Ecosystems 15, 148-161. http://doi.org/10.1007/s10021-011-9499-6.

Chamizo, S., Cantón, Y., Rodríguez-Caballero, E., Domingo, F., Escudero, A. 2012b. Runoff at contrasting scales in a semiarid ecosystem: A complex balance between biological soil crust features and rainfall characteristics. Journal of Hydrology 452-453, 130-138. https://doi. org/10.1016/j.jhydrol.2012.05.045.

Chamizo, S., Rodríguez-Caballero, E., Cantón, Y., Asensio, C., Domingo, F. 2015. Penetration resistance of biological soil crusts and its dynamics after crust removal: Relationships with runoff and soil detachment. Catena 126,164-172. https://doi.org/10.1016/j.catena.2014.11.011.

Chamizo, S., Cantón, Y., Rodríguez-Caballero, E., Domingo, F. 2016. Biocrusts positively affect the soil water balance in semiarid ecosystems. Ecohydrology 9, 1208-1221. http://doi. org/10.1002/eco.1719.

Lázaro, R., Rey, J.M. 1991. Sobre el clima de la provincia de Almería (SE Ibérico). Primer ensayo de cartografía automática de medidas anuales de temperatura y precipitación. Suelo y planta $1,61-68$.

Lázaro, R., Rodrigo, F.S., Gutiérrez, L., Domingo, F., Puigdefábregas. J. 2001. Analysis of a thirty year rainfall record (1967-1997) from semi-arid SE Spain for implications on vegetation. Journal of Arid Environments 48, 373-395. http://doi.org/doi:10.1006/jare.2000.0755.

Lázaro, R., Rodríguez-Tamayo, M.L., Ordiales, R. Puigdefábregas, J. 2004. El Clima. In: J. Mota, J. Cabello, M.I. Cerrillo, M.L. Rodríguez-Tamayo (Eds.), Subdesiertos de Almería: naturaleza de cine. Consejería de Medio Ambiente, Junta de Andalucía, Almería, pp. 63-79.

Lázaro, R., Cantón, Y., Solé-Benet, A., Bevan, J., Alexander, R., García, L., Puigdefábregas, J. 2008. The influence of competition between lichen colonization and erosion on the evolution of soil surfaces in the Tabernas badlands (SE Spain) and its landscape effects. Geomorphology 102, 252-266. http://doi.org/10.1016/j.geomorph.2008.05.005.

López-Bermúdez, F., Boix-Fayos, C., Solé-Benet, A., Albaladejo, J., Barberá, G.G., Del Barrio, G., Castillo, V., García, J., Lázaro, R., Martínez-Mena, M.D., Mosch, W., Navarro-Cano, J.A., Puigdefábregas, J., Sanjuán, M. 2005. Landscapes and desertification in South East Spain. Overview and field sites. Field Trip Guide A-5, 6th International Conference on Geomorphology, Zaragoza. S.E.G., 40 pp. http://www.geomorfologia.es/sites/default/files/ A5\%20Southeast\%20Spain.pdf.

LUCDEME. 1982. Paisajes erosivos en el SE español. Ensayo metodológico para el estudio de su cualificación y cuantificación. Monografías 26.66 pp. + 10 mapas.

Nicolau, J.M., Solé-Benet, A., Puigdefábregas, J., Gutiérrez, L. 1996. Effects of soil and vegetation on runoff along a catena in semi-arid Spain. Geomorphology 14, 297-309. https://doi. org/10.1016/0169-555X(95)00043-5.

Pilgrim, D.H., Chapman, T.G. 1988. Problems of rainfall-runoff modelling in arid and semiarid regions. Hydrological Sciences Journal 33, 379-400. https://doi. org/10.1080/02626668809491261.

Puigdefábregas, J., Del Barrio, G., Boer, M., Gutiérrez, L., Solé, A. 1998. Differential responses of hillslope and channel elements to rainfall events in a semi-arid area. Geomorphology 23, 337-351. https://doi.org/10.1016/S0169-555X(98)00014-2.

Puigdefábregas, J., Solé, A., Gutiérrez, L., Del Barrio, G., Boer, M. 1999. Scales and processes of water and sediment redistribution in drylands: results from the Rambla Honda field site in SE Spain. Earth-Science Reviews 48, 39-70. https://doi.org/10.1016/S0012-8252(99)00046-X. 
Rodríguez-Caballero, E., Cantón, Y., Chamizo, S. Afana, A., Solé-Benet, A. 2012. Effects of biological soil crusts on surface roughness and implications for runoff and erosion. Geomorphology 145-146, 81-89. http://doi.org/10.1016/j.geomorph.2011.12.042.

Rodríguez-Caballero, E., Cantón, Y., Lázaro, R., Solé-Benet, A. 2014a. Cross-scale interactions between surface components and rainfall properties. Non-linearities in the hydrological and erosive behaviour of semiarid catchments. Journal of Hydrology 517, 815-825. http://doi. org/10.1016/j.jhydrol.2014.06.018.

Rodríguez-Caballero, E., Cantón, Y., Lázaro, R., Puigdefábregas, J., Solé-Benet, A. 2014b. Episodios extremos de escorrentía y erosión en los últimos 21 años sobre dos litologías en el semiárido de Almería. In: S. Schnabel, A. Gómez-Gutiérrez (Eds.), Avances en la Geomorfología en España 2012-2014. Sociedad Española de Geomorfología, Zaragoza, pp. 238-241.

Rodríguez-Caballero, E., Castro, A., Chamizo, S., Quintas-Soriano, C., García-Llorente, M., Cantón, Y., Weber, B. 2017. Ecosystem services provided by biocrusts: from ecosystem functions to social values. Journal of Arid environments. https://doi.org/10.1016/j. jaridenv.2017.09.005.

Rojo Serrano, L., Sánchez Fuster, M.C. (Coords.). 1997. Red de estaciones experimentales de seguimiento y evaluación de la erosión y desertificación. RESEL. Proyecto LUCDEME, DGCONA, MIMAM, Madrid.

Slatyer, R.O. 1965. Measurements of precipitation interception by an arid zone plant community (Acacia aneura P. Uuell). UNESCO Arid Zone Research 25, 181-192.

Solé-Benet, A., Calvo, A., Cerdà, A., Lázaro, R., Pini, R., Barbero, J. 1997. Influence of microrelief patterns and plant cover on runoff related processes in badlands from Tabernas (SE Spain). Catena 31, 23-38. https://doi.org/10.1016/S0341-8162(97)00032-5.

Solé-Benet, A., Cantón, Y., Domingo, F., Del Barrio, G., Lázaro, R., Domene, M.A., Vidal, S., Puigdefábregas, J. 2003. Long term hydrological monitoring of two micro-catchments in semi-arid SE Spain. In: L. Holko, P. Miklánek (Eds.), Interdisciplinary approaches in small catchment hydrology: Monitoring and research, IHP-VI, Technical Documents in Hydrology $n^{\circ}$ 67. UNESCO, Paris. pp. 183-188.

Solé-Benet, A., Cantón, Y., Lázaro, R., Puigdefábregas, J. 2009. Meteorización y erosión en el subdesierto de Tabernas, Almería. Cuadernos de Investigación Geográfica 35, 141-163. http:// doi.org/10.18172/cig.1216.

Toms, J.D., Lesperance, M.L. 2003. Piecewise regression: a tool for identifying ecological thresholds. Ecology 84, 2034-2041. http://doi.org/10.1890/02-0472. 